\title{
WholeTree Substrate and Fertilizer Rate in Production of Greenhouse- grown Petunia (Petunia $\times$ hybrida Vilm.) and Marigold (Tagetes patula L.)
}

Glenn B. Fain ${ }^{1,2}$, Charles H. Gilliam, Jeff L. Sibley, and Cheryl R. Boyer Department of Horticulture, 101 Funchess Hall, Auburn University, AL 36849

\author{
Anthony L. Witcher \\ USDA-ARS Southern Horticultural Laboratory, Poplarville, MS 39470
}

Additional index words. media, wood fiber, Pinus taeda, loblolly pine, peatmoss

\begin{abstract}
A substrate component (WholeTree) made from loblolly pine (Pinus taeda $\mathbf{L}$.) was evaluated along with starter fertilizer rate in the production of greenhouse-grown petunia (Petunia $\times$ hybrida Vilm. 'Dreams Purple') and marigold (Tagetes patula L. 'Hero Spry'). Loblolly pine from a 12-year-old plantation were harvested at ground level, chipped, and further processed through a hammer mill to pass a $0.64-\mathrm{cm}$ screen. The resulting WholeTree (WT) substrate was used alone or combined with $20 \%$ (WTP2) or $50 \%$ (WTP5) (by volume) Canadian sphagnum peatmoss and compared with an industry standard peat-lite (PL) mix of 8 peatmoss : 1 vermiculite : 1 perlite (by volume). Substrates were amended with $1.78 \mathrm{~kg} \cdot \mathrm{m}^{-3}$ dolomitic lime, $0.59 \mathrm{~kg} \cdot \mathrm{m}^{-3}$ gypsum $\left[\mathrm{CaSO}_{4}\right.$ $\left.2\left(\mathrm{H}_{2} \mathrm{O}\right)\right], 0.44 \mathrm{~kg} \cdot \mathrm{m}^{-3}$ Micromax, $1.78 \mathrm{~kg} \cdot \mathrm{m}^{-3} 16 \mathrm{~N}-2.6 \mathrm{P}-9.9 \mathrm{~K}$ (3- to 4-month release), and $1.78 \mathrm{~kg} \cdot \mathrm{m}^{-3} 16 \mathrm{~N}-2.6 \mathrm{P}-10.8 \mathrm{~K}(5-$ to 6 -month release). A $7 \mathrm{~N}-1.3 \mathrm{P}-8.3 \mathrm{~K}$ starter fertilizer (SF) was added to each substrate at $0.0,1.19,2.37$, or $3.56 \mathrm{~kg} \cdot \mathrm{m}^{-3}$. Container capacity (CC) was greatest for PL and decreased as the percentage of peatmoss in the substrate decreased with WT having 35\% less CC than PL. Conversely, air space (AS) was greatest for the WT and decreased as percentage of peatmoss increased with PL containing $33 \%$ less AS than WT. In general, petunia dry weight was greatest for any substrate containing peatmoss with a $S F$ rate of $2.37 \mathrm{~kg} \cdot \mathrm{m}^{-3}$ or greater. The exception was that petunia grown in WT at $3.56 \mathrm{~kg} \cdot \mathrm{m}^{-3} \mathrm{SF}$ had similar dry weight as all other treatments. Marigold dry weight was similar for all substrates where at least $2.37 \mathrm{~kg} \cdot \mathrm{m}^{-3} \mathrm{SF}$ was used.
\end{abstract}

Peatmoss is the primary component of substrates in the production of greenhousegrown herbaceous annual crops. Rising transportation cost of peatmoss from Canada or Europe is sure to affect the profitability of many greenhouse operators. Environmental impacts of peat harvesting have been debated for years in Europe. Barkham (1993) stated that there is no longer a need to use peat for the wide variety of garden, commercial, horticultural, and landscape uses for which it has been promoted over the last 30 years. Robertson (1993) reports that despite proven advantages of peat for the horticultural industry, members of the United Kingdom Peat

\footnotetext{
Received for publication 30 Nov. 2007. Accepted for publication $28 \mathrm{Jan} .2008$.

We thank Greg and Bert Young and the staff at Young's Plant Farm, Auburn, AL, for their support of this project.

Mention of trade names or commercial products in this article is solely for the purpose of providing specific information and does not imply recommendation or endorsement by the U.S. Department of Agriculture.

${ }^{1}$ Formerly with USDA-ARS Southern Horticultural Laboratory, Poplarville, MS 39470.

${ }^{2}$ To whom reprint requests should be addressed; e-mailgbf0002@auburn.edu
}

Producers Association (PPA) fully recognized the need to develop alternatives. Robertson stated that members of the PPA produce and market over 100 low-peatmoss or nonpeatmoss products. One of the obstacles to the acceptance of some peatmoss alternatives in Europe is the low cost of peatmoss compared with some of the alternatives being marketed (Noel Gumy, pers. comm., 2006).

Alternative substrate components have been evaluated in the United States for use in greenhouse production. Some substrates have been evaluated as additions to reduce the quantities of peatmoss in a given substrate and others as peatmoss replacements. Conover and Poole (1983) evaluated a substrate component made from melaleuca [Melaleuca quinquenervia (Cav.) S.T. Blake] trees. In this study, the entire aboveground portion of 3 - to $10-\mathrm{cm}$ diameter trees were chipped and then ground to pass a $5-\mathrm{cm}$ screen. Results indicated up to $25 \%$ (by volume) melaluca could be used as a substrate component in the production of Ficus benjamina L. and Dracena marginata Lam. Kenna and Whitcomb (1985) used ground noncomposted post oak (Quercus stellata Wangenh.) and Siberian elm (Ulmus pumila L.) as substrate components. Both the oak and elm substrates when mixed 3 oak or elm : 1 sphagnum peatmoss : 1 sand (by volume) produced container formosan sweetgum (Liquidambar formosana Hance) and mojave pyracantha [Pyracantha (M. Roemer) $\times$ 'Mojave'] equal to those in a standard pinebark substrate. Coconut coir has shown promise as a peatmoss substitute (Evans and Stamps, 1996). However, high transportation costs from Sri Lanka and Malaysia and inconsistency in quality (Bragg, 1991) have limited widespread acceptance and use of coir in comparison with peatmoss. Cotton gin compost, a waste product of the cotton industry, has shown promise as an alternative substrate (Owings, 1993). Vermicompost, a product resulting from the breakdown of agricultural wastes by earthworms, has been successfully used in greenhouse production (Bachman and Metzger, 1998). Evans (2004) demonstrated that geranium (Pelargonium $\times$ hortorum Bailey) and vinca (Catharanthus roseus L.) when grown in a substrate containing up to $30 \%$ processed poultry feather fiber were not significantly different from those grown in 4 sphagnum peatmoss : 1 perlite (by volume). With many, if not all, of the alternative substrates that have been evaluated, the biggest obstacle to widespread use is the availability of a consistent quality product in quantities large enough to sustain the horticultural industry into the future.

Extensive research has been conducted outside the United States on peat alternatives. Some of the more promising alternatives that might have potential in the United States are those made of wood fiber from coniferous trees. Studies by Gruda and Schnitzler (2001) and Gruda et al. (2000a, 2000b) demonstrated the suitability of wood fiber substrates made from spruce [Picea abies (L.) Karst] wood chips as an alternative for peatmoss-based substrates in cultivation of lettuce seedlings (Lactuca sativa L. var. capitata) and tomato transplants [Lycopersicon lycopersicum (L.) Karst. Ex Farw.]. Muro et al. (2005) compared a pine fiber substrate (Fibralur) made from sawmill residues with coir and perlite in hydroponic production of tomatoes and found Fibralur produced similar tomato yields both quantitatively and qualitatively as those of coir and perlite.

Although not on the market in the United States, there are at least seven well-known wood fiber products marketed in Europe (Gumy, 2001). Estimates from Germany in 1999 revealed that over $235,000 \mathrm{~m}^{3}$ of wood fiber is marketed annually. Recently, research has been conducted in the United States on high wood fiber content substrates. Wright and Browder (2005) demonstrated that Japanese holly (Ilex crenata Thunb. 'Chesapeake') grown in a substrate made from loblolly pine chips performed as well as those grown in standard pinebark (PB) substrate when pine chips received periodic liquid feeds of $\mathrm{N}-\mathrm{P}-\mathrm{K}$ to maintain electrical conductivity (EC) readings near those of $\mathrm{PB}$. In the same study, marigold (Tagetes erecta Big. 'Inca Gold') grown in a 3 pine chips: 1 pinebark (by volume) substrate were equal to 
Table 1. Physical properties of substrates. ${ }^{z}$

\begin{tabular}{|c|c|c|c|c|}
\hline & $\begin{array}{c}\text { Air } \\
\text { space }\end{array}$ & $\begin{array}{c}\text { Container } \\
\text { capacity }\end{array}$ & $\begin{array}{c}\text { Total } \\
\text { porosity }\end{array}$ & \multirow{2}{*}{$\begin{array}{l}\text { Bulk density } \\
\quad\left(\mathrm{g} \cdot \mathrm{cm}^{-3}\right)\end{array}$} \\
\hline Substrates & \multicolumn{3}{|c|}{ 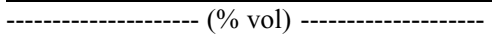 } & \\
\hline $100 \%$ WholeTree $(\mathrm{WT})$ & 49.5 & 41.0 & 90.5 & 0.130 \\
\hline $4 \mathrm{WT}: 1$ peatmoss (WTP2) & 39.8 & 51.0 & 90.8 & 0.127 \\
\hline $1 \mathrm{WT}: 1$ peatmoss (WTP5) & 33.0 & 62.1 & 95.1 & 0.099 \\
\hline 8 peatmoss : 1 perlite : & & & & \\
\hline 1 vermiculite $(\mathrm{PL})$ & 16.3 & 75.9 & 92.2 & 0.104 \\
\hline $\operatorname{HSD}^{\mathrm{x}}$ & 4.0 & 4.4 & 2.0 & 0.008 \\
\hline
\end{tabular}

${ }^{\mathrm{z}}$ Analysis performed using the NCSU porometer.

${ }^{\mathrm{y}}$ Processed whole pine tree (Pinus taeda) shoots ground to pass a $0.64-\mathrm{cm}$ screen.

${ }^{x}$ Tukey's honest significant difference $(P \leq 0.05, \mathrm{n}=4)$. those grown in a $100 \%$ pinebark substrate when additional nutrients were applied to pine chip substrate. More recently, Boyer et al. (2006a) and Fain et al. (2006) have evaluated a substrate made from all aboveground portions of loblolly pine (WholeTree). Boyer et al. (2006a) reported that container-grown lantana (Lantana camara L.) could be produced in substrates containing from $50 \%$ to $100 \%$ WholeTree. Fain et al. (2006) reported that greenhouse-grown marigold in a 4 WholeTree : 1 sphagnum peatmoss

Table 2. Particle size distribution of substrates.

\begin{tabular}{|c|c|c|c|c|c|c|c|c|c|c|c|c|c|c|c|}
\hline \multirow[b]{2}{*}{ Substrates } & \multicolumn{12}{|c|}{ Sieve opening $(\mathrm{mm})$} & \multicolumn{3}{|c|}{ Texture group ${ }^{z}$} \\
\hline & 9.50 & 6.35 & 3.35 & 2.36 & 2.00 & 1.40 & 1.00 & 0.50 & 0.25 & 0.11 & 0.05 & $\overline{P a n}$ & $\overline{\text { Coarse }}$ & Medium & $\overline{\text { Fine }}$ \\
\hline $4 \mathrm{WT}: 1$ peatmoss (WTP2) & 0.0 & 0.4 & 15.9 & 23.1 & 9.4 & 15.0 & 9.3 & 10.7 & 7.4 & 6.2 & 2.1 & 0.6 & 48.7 & 34.9 & 16.4 \\
\hline 8 peatmoss : 1 perlite : & & & & & & & & & & & & & & & \\
\hline 1 vermiculite $(\mathrm{PL})$ & 0.9 & 2.2 & 6.3 & 8.3 & 4.1 & 10.9 & 10.9 & 25.4 & 17.6 & 10.1 & 2.4 & 0.8 & 21.9 & 47.2 & 30.9 \\
\hline $\mathrm{HSD}^{\mathrm{w}}$ & 1.5 & 0.7 & 2.2 & 2.1 & 1.2 & 1.3 & 0.8 & 0.8 & 2.1 & 2.9 & 0.9 & 0.2 & 4.5 & 2.3 & 6.0 \\
\hline
\end{tabular}

${ }^{\mathrm{z}}$ Coarse $\geq 2.0 \mathrm{~mm}$; medium $<2.0 \mathrm{~mm}$ to $\geq 1.0 \mathrm{~mm}$; fine $<1.0 \mathrm{~mm}$.

y Processed whole pine tree (Pinus taeda) shoots ground to pass a $0.64-\mathrm{cm}$ screen.

xPercent weight of 100-g sample collected on each screen

wTukey's honest significant difference $(P \leq 0.05, \mathrm{n}=3)$.

Table 3. Effects of starter fertilizer rate and substrate on $\mathrm{pH}$ and electrical conductivity at two different growing locations.

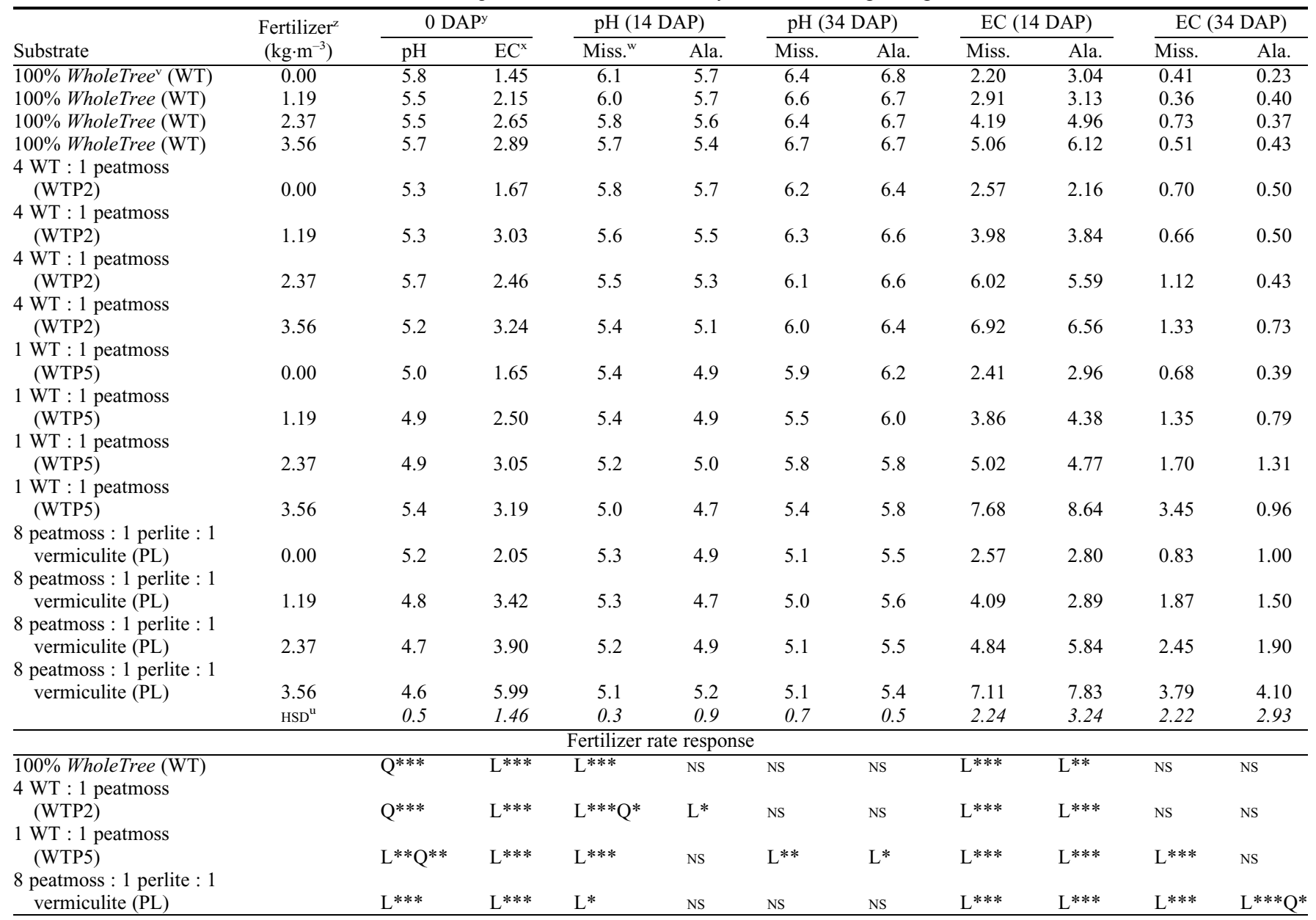

${ }^{\mathrm{z}}$ Supplemental starter fertilizer $(7 \mathrm{~N}-1.3 \mathrm{P}-8.2 \mathrm{~K})$.

${ }^{\mathrm{y}}$ Days after potting.

${ }^{\mathrm{x}}$ Electrical conductivity $(\mathrm{dS} \cdot \mathrm{cm})$ of substrate solution using the pourthrough method.

wesults from USDA-ARS Southern Horticultural Laboratory, Poplarville, MS (Miss.) and Young's Plant Farm, Auburn, AL (Ala.).

${ }^{v}$ Processed whole pine tree (Pinus taeda) shoots ground to pass a $0.64-\mathrm{cm}$ screen.

"Tukey's honest significant difference $(P \leq 0.05, \mathrm{n}=4)$

${ }^{\mathrm{N}}$ Nonsignificant; $\mathrm{L}=$ linear; or $\mathrm{Q}=$ quadratic response at $P \leq 0.05(*), 0.01(* *)$, or $0.001(* * *)$ based on single degree-of-freedom orthogonal contrasts 
Table 4. Effects of starter fertilizer rate and substrate on growth of Petunia $\times$ hybrida Dreams Purple at two different growing locations.

\begin{tabular}{|c|c|c|c|c|c|c|c|c|c|}
\hline \multirow[b]{2}{*}{ Substrate } & \multirow{2}{*}{$\begin{array}{c}\text { Fertilizer }^{\mathrm{Z}} \\
\left(\mathrm{kg} \cdot \mathrm{m}^{-3}\right)\end{array}$} & \multicolumn{2}{|c|}{$\mathrm{LG}^{\mathrm{y}}$} & \multicolumn{2}{|c|}{ Flower (ct) } & \multicolumn{2}{|c|}{$\mathrm{GI}^{\mathrm{x}}(\mathrm{cm})$} & \multicolumn{2}{|c|}{ Dry $w^{w}(g)$} \\
\hline & & Miss. $^{v}$ & $\overline{\text { Ala. }}$ & Miss. & $\overline{\text { Ala. }}$ & Miss. & Ala. & Miss. & Ala. \\
\hline 100\% WholeTree $(\mathrm{WT})$ & 0.00 & 35.2 & 34.6 & 1.1 & 2.6 & 29.5 & 27.5 & 7.2 & 5.1 \\
\hline $100 \%$ WholeTree (WT) & 1.19 & 33.7 & 34.4 & 3.6 & 8.4 & 33.0 & 30.3 & 9.8 & 7.2 \\
\hline $100 \%$ WholeTree (WT) & 2.37 & 34.0 & 35.0 & 4.9 & 8.3 & 34.9 & 32.6 & 13.2 & 7.4 \\
\hline $100 \%$ WholeTree (WT) & 3.56 & 32.8 & 33.3 & 2.8 & 5.4 & 37.1 & 35.5 & 14.0 & 8.0 \\
\hline $4 \mathrm{WT}: 1$ peatmoss (WTP2) & 0.00 & 36.4 & 34.1 & 2.3 & 5.4 & 31.9 & 28.7 & 10.2 & 5.9 \\
\hline $4 \mathrm{WT}: 1$ peatmoss (WTP2) & 1.19 & 35.6 & 34.3 & 5.0 & 7.9 & 34.4 & 30.7 & 13.3 & 7.3 \\
\hline $4 \mathrm{WT}: 1$ peatmoss (WTP2) & 2.37 & 35.6 & 32.0 & 3.5 & 6.5 & 37.6 & 35.7 & 15.3 & 8.4 \\
\hline $4 \mathrm{WT}: 1$ peatmoss (WTP2) & 3.56 & 35.1 & 35.0 & 6.4 & 6.6 & 38.6 & 34.7 & 16.8 & 8.5 \\
\hline $1 \mathrm{WT}: 1$ peatmoss (WTP5) & 0.00 & 38.1 & 37.1 & 7.9 & 14.6 & 36.2 & 31.0 & 13.1 & 7.5 \\
\hline $1 \mathrm{WT}: 1$ peatmoss (WTP5) & 1.19 & 37.5 & 35.7 & 6.9 & 10.8 & 39.4 & 36.6 & 16.5 & 8.9 \\
\hline $1 \mathrm{WT}: 1$ peatmoss (WTP5) & 2.37 & 40.0 & 37.1 & 7.9 & 11.3 & 40.4 & 37.5 & 18.9 & 9.4 \\
\hline $1 \mathrm{WT}: 1$ peatmoss (WTP5) & 3.56 & 38.5 & 34.9 & 5.9 & 13.8 & 40.4 & 38.4 & 18.5 & 10.1 \\
\hline 8 peatmoss : 1 perlite : 1 vermiculite $(\mathrm{PL})$ & 0.00 & 38.2 & 40.6 & 12.5 & 13.8 & 37.4 & 36.5 & 15.5 & 9.1 \\
\hline 8 peatmoss : 1 perlite : 1 vermiculite (PL) & 1.19 & 38.3 & 36.1 & 16.0 & 16.5 & 41.6 & 36.7 & 18.1 & 10.3 \\
\hline 8 peatmoss : 1 perlite : 1 vermiculite $(\mathrm{PL})$ & 2.37 & 38.0 & 36.6 & 8.1 & 13.8 & 42.3 & 38.1 & 19.0 & 10.0 \\
\hline 8 peatmoss : 1 perlite : 1 vermiculite (PL) & 3.56 & 38.7 & 35.5 & 9.5 & 7.1 & 42.4 & 38.1 & 18.7 & 9.1 \\
\hline & $\mathrm{HSD}^{\mathrm{t}}$ & 4.8 & 7.1 & 6.4 & 12.0 & 4.1 & 5.7 & 4.1 & 2.8 \\
\hline \multicolumn{10}{|c|}{ Fertilizer rate response } \\
\hline 100\% WholeTree (WT) & & $\mathrm{NS}^{\mathrm{s}}$ & NS & NS & NS & $\mathrm{L}^{* * *}$ & $\mathrm{~L}^{* * *}$ & $\mathrm{~L}^{* * *}$ & $\mathrm{~L}^{* * *}$ \\
\hline 4 WT : 1 peatmoss (WTP2) & & NS & NS & $\mathrm{L}^{*}$ & NS & $\mathrm{L} * * *$ & $\mathrm{~L}^{* * *}$ & $\mathrm{~L} * * *$ & $\mathrm{~L} * * *$ \\
\hline 1 WT : 1 peatmoss (WTP5) & & NS & NS & NS & NS & $\mathrm{L} * * *$ & $\mathrm{~L} * * * \mathrm{Q} *$ & $\mathrm{~L}^{* * *} \mathrm{Q} *$ & $\mathrm{~L}^{* *}$ \\
\hline 8 peatmoss : 1 perlite : 1 vermiculite (PL) & & NS & $\mathrm{L}^{*}$ & NS & NS & $\mathrm{L}^{* * *} \mathrm{Q}^{*}$ & NS & $\mathrm{L} * *$ & NS \\
\hline
\end{tabular}

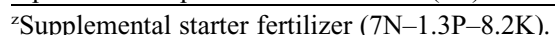

${ }^{\mathrm{y}}$ Leaf greenness (chlorophyll content) quantified using a SPAD-502 chlorophyll meter (average of four leaves per plant).

${ }^{\mathrm{x}}$ Growth Index in centimeters [(height + width + perpendicular width)/3].

wPlant shoot dry weight in grams.

v'Results from USDA-ARS Southern Horticultural Laboratory, Poplarville, MS (Miss.) and Young's Plant Farm, Auburn, AL (Ala.).

urocessed whole pine tree (Pinus taeda) shoots ground to pass a $0.64-\mathrm{cm}$ screen.

'Tukey's honest significant difference $(P \leq 0.05, \mathrm{n}=4)$.

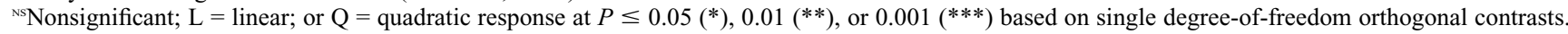

(by volume) substrate equaled those grown in an 8 sphagnum peatmoss : 1 vermiculite : 1 perlite (by volume) substrate. Boyer et al. (2006b) evaluated an alternative substrate made from a forestry residue generated from an in-field clean chipping operation. Clean chip residual (CCR) contains $\approx 50 \%$ wood fiber. Ageratum (Ageratum houstonianum P. Mill. 'Blue Hawaii') greenhouse-grown in 2.8-L containers in a 4 pinebark : 1 peat (by volume) or a 4 CCR : 1 peatmoss (by volume) substrate had similar growth.

Initial concern is that nutritional requirements might be different with WholeTree compared with standard substrates. This concern comes about as a result of previous studies comparing 100\% WholeTree with a 8 peatmoss : 1 vermiculite : 1 perlite (by volume) substrate (Fain et al., 2008) in production of marigold and petunia. With identical fertilizer programs, plants in WholeTree substrates were smaller and of lesser quality than those grown in the peatlite substrate. These differences could have been the result of differences in physical properties [increased air space (AS) and decreased container capacity (CC)] and low cation exchange capacity (CEC), leading to nutrient leaching or possible $\mathrm{N}$ immobilization from chemical or microbial activity. Nitrogen immobilization has been reported in wood substrates (Fischer, 1994; Grantzau, 1991). Gruda et al. (2000b) reported on the effects of impregnation of wood substrates with nutrients to reduce harmful effects on transplants resulting from $\mathrm{N}$ deficiency. Although not mentioned by Wright and Browder (2005), the added nutrients needed to raise the EC of their pine chip substrates could partly be the result of $\mathrm{N}$ immobilization. The objective of this research was to evaluate supplemental starter fertilizer rate in combination with WholeTree as an alternative growth substrate and substrate component for greenhouse-grown herbaceous annual crops.

\section{Materials and Methods}

Studies were conducted at the USDAARS Southern Horticultural Laboratory in Poplarville, MS, and Young's Plant Farm in Auburn, AL. Loblolly pine (Pinus taeda) was harvested from a 12-year-old plantation in Evergreen, AL, at ground level and fed through a portable heavy-duty horizontal grinder with $10.19-\mathrm{cm}$ screens (Peterson 4700B; Peterson Pacific Corp. Eugene, OR). This material was then further processed through a hammer mill with a 0.64 $\mathrm{cm}$ screen (C.S. Bell No. 30, Tiffin, $\mathrm{OH}$ ). The resulting substrate was used alone [WholeTree (WT)] or combined with 20\% (WTP2) or $50 \%$ (WTP5) (by volume) Canadian sphagnum peatmoss and compared with an industry standard peat-lite (PL) mix of 8 peatmoss : 1 vermiculite : 1 perlite (by volume). Substrates were amended with $1.78 \mathrm{~kg} \cdot \mathrm{m}^{-3}$ dolomitic lime, $0.59 \mathrm{~kg} \cdot \mathrm{m}^{-3}$ gypsum $\left[\mathrm{CaSO}_{4}-2\left(\mathrm{H}_{2} \mathrm{O}\right)\right], \quad 0.44 \mathrm{~kg} \cdot \mathrm{m}^{-3}$ Micromax (O.M. Scotts Co., Marysville, $\mathrm{OH}), 1.78 \mathrm{~kg} \cdot \mathrm{m}^{-3} 16 \mathrm{~N}-2.6 \mathrm{P}-9.9 \mathrm{~K}$ (Harrell's 3-4 month, Sylacauga, AL), and $1.78 \mathrm{~kg} \cdot \mathrm{m}^{-3}$ $16 \mathrm{~N}-2.6 \mathrm{P}-10.8 \mathrm{~K}$ (Harrell's 5-6 month). A $7 \mathrm{~N}-1.3 \mathrm{P}-8.3 \mathrm{~K}$ starter fertilizer (SF) (Harrell's custom formulation) was added to each substrate at $0.0,1.19,2.37$, or $3.56 \mathrm{~kg} \cdot \mathrm{m}^{-3}$.
The SF also contained $10.7 \%$ calcium nitrate (Ca) and $0.36 \%$ manganese sulfate $(\mathrm{Mg})$. On 27 June 2006 (23 June 2006 for Alabama) 1.57-L containers (AZF0600; ITML Horticultural Products Inc. Brantford, Ontario, Canada) were filled with substrates level to the top of the container and four $6-\mathrm{cm}^{3}$ plugs grown in 288-cell flats (PLG2880; ITML Horticultural Products Inc.) of either marigold (Tagetes patula 'Hero Spry'; 4 to 5 weeks from sowing) or petunia (Petunia $\times$ hybrida 'Dreams Purple' 6 to 7 weeks from sowing) were planted into each container. Containers were placed in a corrugated polycarbonate covered greenhouse (glass at Young's Plant Farm) on elevated benches and hand-watered as needed.

Substrates were analyzed for particle size distribution by passing a 100-g air-dried sample through 9.50-, 6.35-, 3.35-, 2.36-, $2.0-, 1.4-, 1.0-, 0.50-, 0.25-, 0.11-$, and $0.05-$ $\mathrm{mm}$ sieves with particles $\leq 0.05 \mathrm{~mm}$ collected in a pan. Sieves were shaken for $3 \mathrm{~min}$ with a Ro-Tap (Ro-Tap RX-29; W.S. Tyler, Mentor, $\mathrm{OH}$ ) sieve shaker (278 oscillations/ min, 159 taps/min). Substrate AS, CC, and total porosity (TP) were determined following procedures described by Bilderback et al. (1982). Substrate bulk density $\left(\mathrm{g} \cdot \mathrm{cm}^{-3}\right)$ was determined from $347.5-\mathrm{cm}^{3}$ samples dried in a $105^{\circ} \mathrm{C}$ forced air oven for $48 \mathrm{~h}$. Before planting, $\mathrm{pH}$ and $\mathrm{EC}$ were determined (Accumet Excel XL50; Fisher Scientific, Pittsburgh, PA) using the pourthrough method (Wright, 1986). Subsequently $\mathrm{pH}$ and $\mathrm{EC}$ were taken at both locations at 14 and $34 \mathrm{~d}$ after potting (DAP). At 34 DAP, all plants were measured for growth index [ (height + width 
Table 5. Effects of starter fertilizer rate and substrate on growth of Tagetes patula Hero Spry at two different growing locations.

\begin{tabular}{|c|c|c|c|c|c|c|c|c|c|c|}
\hline \multirow[b]{2}{*}{ Substrate } & \multirow{2}{*}{$\begin{array}{c}\text { Fertilizer }^{z} \\
\left(\mathrm{~kg} \cdot \mathrm{m}^{-3}\right)\end{array}$} & \multicolumn{2}{|c|}{$\mathrm{LG}^{\mathrm{y}}$} & \multicolumn{2}{|c|}{ Flower (ct) } & \multicolumn{2}{|c|}{ Root rating $^{x}$} & \multicolumn{2}{|c|}{ Dry $w^{w}{ }^{w}(g)$} & \multirow{2}{*}{$\begin{array}{l}\text { Shrinkage } \\
\text { (cm) }\end{array}$} \\
\hline & & Miss. $^{v}$ & $\overline{\text { Ala. }}$ & Miss. & $\overline{\text { Ala. }}$ & Miss. & $\overline{\text { Ala. }}$ & Miss. & Ala. & \\
\hline 100\% WholeTree $(\mathrm{WT})$ & 0.00 & 46.5 & 39.4 & 22.3 & 13.4 & 4.1 & 2.9 & 7.2 & 3.9 & 1.9 \\
\hline 100\% WholeTree (WT) & 1.19 & 46.5 & 43.6 & 24.6 & 14.5 & 4.2 & 3.0 & 8.2 & 5.5 & 2.1 \\
\hline $100 \%$ WholeTree (WT) & 2.37 & 49.3 & 44.6 & 22.1 & 13.4 & 3.6 & 3.4 & 8.6 & 5.8 & 2.1 \\
\hline $100 \%$ WholeTree (WT) & 3.56 & 51.2 & 44.2 & 19.0 & 13 & 3.7 & 3.5 & 8.5 & 5.3 & 2.2 \\
\hline $4 \mathrm{WT}: 1$ peatmoss (WTP2) & 0.00 & 47.1 & 44.1 & 20.8 & 13.9 & 3.8 & 2.7 & 7.4 & 5.1 & 2.0 \\
\hline $4 \mathrm{WT}: 1$ peatmoss (WTP2) & 1.19 & 51.3 & 46.3 & 23.5 & 16.3 & 4.0 & 3.0 & 9.7 & 6.8 & 2.1 \\
\hline $4 \mathrm{WT}: 1$ peatmoss (WTP2) & 2.37 & 49.4 & 45.6 & 19.4 & 14.3 & 3.5 & 3.3 & 8.9 & 6.5 & 2.3 \\
\hline $4 \mathrm{WT}: 1$ peatmoss (WTP2) & 3.56 & 50.2 & 46.4 & 18.0 & 14.9 & 3.4 & 3.3 & 8.6 & 6.3 & 2.1 \\
\hline $1 \mathrm{WT}: 1$ peatmoss (WTP5) & 0.00 & 48.8 & 43.2 & 20.9 & 11.8 & 4.2 & 3.1 & 9.7 & 6.0 & 2.5 \\
\hline $1 \mathrm{WT}: 1$ peatmoss (WTP5) & 1.19 & 53.5 & 46.7 & 18.6 & 15.6 & 3.6 & 3.1 & 9.1 & 7.1 & 2.7 \\
\hline $1 \mathrm{WT}: 1$ peatmoss (WTP5) & 2.37 & 49.8 & 45.9 & 15.0 & 11.9 & 3.3 & 2.9 & 8.7 & 7.1 & 2.4 \\
\hline $1 \mathrm{WT}: 1$ peatmoss (WTP5) & 3.56 & 52.3 & 45.0 & 19.1 & 10.6 & 2.9 & 3.1 & 9.2 & 6.8 & 2.6 \\
\hline 8 peatmoss : 1 perlite : 1 vermiculite $(\mathrm{PL})$ & 0.00 & 51.6 & 49.7 & 21.1 & 12.9 & 3.3 & 2.5 & 10.1 & 6.7 & 2.5 \\
\hline 8 peatmoss : 1 perlite : 1 vermiculite (PL) & 1.19 & 53.2 & 48.5 & 16.9 & 11.9 & 3.3 & 2.8 & 9.9 & 7.2 & 2.4 \\
\hline 8 peatmoss : 1 perlite : 1 vermiculite (PL) & 2.37 & 50.9 & 48.6 & 16.6 & 12.3 & 3.1 & 2.4 & 9.3 & 6.8 & 2.5 \\
\hline \multirow[t]{2}{*}{8 peatmoss : 1 perlite : 1 vermiculite (PL) } & 3.56 & 53.1 & 49.4 & 16.0 & 12.6 & 2.9 & 2.6 & 8.6 & 6.1 & 2.5 \\
\hline & $\operatorname{HSD}^{\mathrm{t}}$ & 4.3 & 6.1 & 6.6 & 6.9 & 0.9 & 0.8 & 2.6 & 1.6 & 0.48 \\
\hline \multicolumn{11}{|c|}{ Fertilizer rate response } \\
\hline 100\% WholeTree (WT) & & $\mathrm{L}^{* * *}$ & $\mathrm{~L}^{* *}$ & $\mathrm{Q}^{*}$ & NS & NS & $\mathrm{L}^{*} \mathrm{Q}^{*}$ & NS & $\mathrm{L}^{* *} \mathrm{Q}^{*}$ & $\mathrm{~L}^{*}$ \\
\hline 4 WT : 1 peatmoss (WTP2) & & $\mathrm{L}^{*}$ & NS & NS & NS & NS & $\mathrm{L}^{* *}$ & $\mathrm{Q}^{*}$ & $\mathrm{~L}^{*}$ & NS \\
\hline $1 \mathrm{WT}: 1$ peatmoss (WTP5) & & $\mathrm{L}^{* *}$ & NS & $\mathrm{Q}^{*}$ & NS & $\mathrm{L} * * *$ & NS & NS & $\mathrm{Q}^{*}$ & NS \\
\hline 8 peatmoss : 1 perlite : 1 vermiculite (PL) & & NS & NS & $\mathrm{L} * *$ & NS & NS & NS & $\mathrm{L}^{*}$ & NS & NS \\
\hline
\end{tabular}

'Supplemental starter fertilizer $(7 \mathrm{~N}-1.3 \mathrm{P}-8.2 \mathrm{~K})$.

${ }^{\mathrm{y}}$ Leaf greenness (chlorophyll content) quantified using a SPAD-502 chlorophyll meter (average of four leaves per plant).

${ }^{x}$ Root rating on a scale of 0 to 5 where $0=$ no roots visible at substrate container interface and $5=$ roots covering $100 \%$.

wPlant shoot dry weight in grams.

'Results from USDA-ARS Southern Horticultural Laboratory, Poplarville, MS (Miss.) and Young's Plant Farm, Auburn, AL (Ala.).

"Processed whole pine tree (Pinus taeda) shoots ground to pass a 0.64-cm screen.

'Tukey's honest significant difference $(P \leq 0.05, \mathrm{n}=4)$.

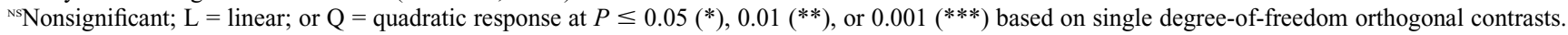

+ perpendicular width $) \div 3]$, leaf greenness (SPAD 502 Chlorophyll Meter; Minolta Camera Co., Ramsey, NJ), and flower count (number flower buds showing color). Roots were visually inspected and rated on a scale of 0 to 5 with 0 indicating no roots present at the container substrate interface and 5 indicating roots visible at all portions of the container substrate interface. Substrate shrinkage (in centimeters) was measured from the top of the container to the top of substrate surface. Recently matured leaves were sampled from four replications of each substrate for petunia plants at both locations (Mills and Jones, 1996). Petunia foliar samples were analyzed for $\mathrm{N}, \mathrm{P}, \mathrm{K}, \mathrm{Ca}, \mathrm{Mg}, \mathrm{S}, \mathrm{B}, \mathrm{Fe}, \mathrm{Mn}, \mathrm{Cu}$, and $\mathrm{Zn}$. Foliar $\mathrm{N}$ was determined by combustion analysis using a $1500 \mathrm{~N}$ analyzer (Carlo Erba, Milan, Italy). Remaining nutrients were determined by microwave digestion with inductively coupled plasma-emission spectrometry (Thermo Jarrel Ash, Offenbach, Germany). At 34 DAP, petunia and marigold shoots were removed at the substrate surface and ovendried at $70{ }^{\circ} \mathrm{C}$ for $72 \mathrm{~h}$ and weighed.

Containers in Mississippi were arranged in a randomized complete block (RCB) with eight single-plant replicates, whereas containers in Alabama were arranged in a RCB with four replicates containing three subsamples per experimental unit. Data were subjected to analysis of variance using the general linear models procedure and multiple comparison of means was conducted using Tukey's honest significant difference test (Version 9.1; SAS Institute, Cary, NC. Starter fertilizer rate was tested for a linear or quadratic response using single degree of freedom orthogonal contrasts (Version 9.1; SAS Institute Inc.).

\section{Results and Discussion}

Physical properties analysis (Table 1) revealed that TP was similar for three of the four substrates with TP of WTP5 3\% to 5\% higher than the other substrates. Container capacity was greatest for PL and decreased as the percentage of peatmoss in the substrate decreased with WT having 35\% less CC than PL. Conversely AS was greatest for the WT and decreased as percentage of peatmoss increased with PL containing 33\% less AS than WT. Particle size distribution provides some explanation for the differences in AS and CC (Table 2). Particle sizes were placed into texture groups of coarse $(\geq 2.0 \mathrm{~mm})$, medium $(<2.0 \mathrm{~mm}$ to $\geq 1.0 \mathrm{~mm})$, and fine $(<1.0 \mathrm{~mm})$. Peat-lite substrate contained 2.7 times more fine particles than the $100 \%$ WT substrates. According to Bohne and Günther (1997), a reduction in particle size leads to a decrease in AS and an increase in CC. Gruda et al. (2000a) reported a strong correlation between the amount of particles smaller than $1 \mathrm{~mm}$ and the maximum water capacity of wood fiber substrates. This is also supported by Saunders et al. (2006), who showed that a decrease in fine particles of wood substrate resulted in a decrease in CC. Peatlite substrate had the greatest percentage of mediumsized particles having $\approx 1.4$ times as many as substrates containing any WT.

In an inverse relationship to the amount of fine particles WT had the greatest quantity of coarse particles having 1.1 to 2.5 times as many as any other substrate. Substrate bulk density was significantly highest for WT and WTP2. This greater bulk density is most likely the result of the greater density and larger quantity of coarse particles of the WholeTree component.

Before planting, substrate EC increased linearly with increasing SF rate for all substrates (Table 3). EC was similar between all substrates within each SF rate with the exception of the $3.56 \mathrm{~kg} \cdot \mathrm{m}^{-3}$ in which PL substrate had the highest EC at $5.99 \mathrm{dS} \cdot \mathrm{cm}^{-1}$. By 34 DAP, there was no difference in EC between WT (Alabama and Mississippi), WTP2 (Alabama and Mississippi), and WTP5 (Alabama only) and SF rate effect had diminished in these substrates. However, WTP5 in Mississippi and PL at both locations had increased EC with increasing SF rate.

In general, $\mathrm{pH}$ was higher for WT and decreased with addition of peatmoss with PL substrate having the lowest $\mathrm{pH}$ (Table 3). By 34 DAP, $\mathrm{pH}$ was highest for WT and lowest for PL at both locations. With the exception of PL at the Southern Horticultural Laboratory where $\mathrm{pH}$ averaged 5.1, substrates containing peatmoss had a $\mathrm{pH}$ within the recommended range of 5.4 of 6.2 (Argo and Fisher, 2002). Although within the recommended range before potting and 14 DAP, $\mathrm{pH}$ for WT was at or above the upper end of that range at $34 \mathrm{DAP}$

Neither substrate nor SF rate had any effect on leaf greenness for Petunia (Table 4). However, leaf greenness increased with increasing fertilizer rate for marigold grown in WT, WTP2, or WTP5 in Mississippi and 
Table 6. Effects of starter fertilizer rate and substrate on tissue macronutrient content of Petunia $\times$ hybrida Dreams Purple at two different growing locations.

\begin{tabular}{|c|c|c|c|c|c|c|c|c|c|c|c|c|c|}
\hline \multirow[b]{2}{*}{ Substrate } & \multirow{2}{*}{$\begin{array}{c}\text { Fertilizer }^{2} \\
\left(\mathrm{~kg} \cdot \mathrm{m}^{-3}\right)\end{array}$} & \multicolumn{2}{|c|}{$\mathrm{N}(\%)$} & \multicolumn{2}{|c|}{$\mathrm{P}(\%)$} & \multicolumn{2}{|c|}{$\mathrm{K}(\%)$} & \multicolumn{2}{|c|}{$\mathrm{Ca}(\%)$} & \multicolumn{2}{|c|}{$\operatorname{Mg}(\%)$} & \multicolumn{2}{|c|}{$\mathrm{S}(\%)$} \\
\hline & & Miss. $^{y}$ & Ala. & Miss. & Ala. & Miss. & Ala. & Miss. & Ala. & Miss. & Ala. & Miss. & Ala. \\
\hline $100 \%$ WholeTree (WT) & 1.19 & 4.73 & 4.12 & 0.41 & 0.33 & 4.77 & 4.24 & 1.02 & 1.02 & 0.32 & 0.32 & 0.62 & 0.79 \\
\hline $100 \%$ WholeTree (WT) & 3.56 & 4.59 & 5.14 & 0.36 & 0.45 & 3.58 & 4.64 & 1.21 & 1.30 & 0.33 & 0.36 & 0.50 & 0.67 \\
\hline $4 \mathrm{WT}: 1$ peatmoss (WTP2) & 0.00 & 3.90 & 3.57 & 0.33 & 0.35 & 3.38 & 3.75 & 0.84 & 1.01 & 0.31 & 0.31 & 0.66 & 0.69 \\
\hline $4 \mathrm{WT}: 1$ peatmoss (WTP2) & 1.19 & 4.00 & 4.10 & 0.30 & 0.34 & 3.01 & 4.21 & 0.91 & 1.07 & 0.31 & 0.34 & 0.54 & 0.73 \\
\hline $4 \mathrm{WT}: 1$ peatmoss (WTP2) & 2.37 & 4.40 & 5.20 & 0.31 & 0.40 & 2.84 & 4.16 & 1.06 & 1.21 & 0.36 & 0.40 & 0.52 & 0.62 \\
\hline $1 \mathrm{WT}: 1$ peatm & 1.19 & 4.18 & 5.15 & 0.28 & 0.39 & 2.07 & 3.19 & 0.83 & 0.96 & 0.37 & 0.45 & 0.49 & 0.63 \\
\hline $1 \mathrm{WT}: 1$ peatmoss (WTP5) & 2.37 & 4.53 & 5.50 & 0.32 & 0.42 & 2.15 & 3.24 & 0.94 & 1.05 & 0.42 & 0.49 & 0.50 & 0.64 \\
\hline $1 \mathrm{WT}: 1$ peatmoss (WTP5) & 3.56 & 4.81 & 5.42 & 0.35 & 0.46 & 2.17 & 3.19 & 1.05 & 1.11 & 0.43 & 0.46 & 0.57 & 0.63 \\
\hline 8 peatmoss : 1 perlite : 1 vermiculite (PL) & 0.00 & 4.07 & 5.86 & 0.24 & 0.44 & 3.21 & 4.23 & 0.63 & 0.84 & 0.33 & 0.51 & 0.62 & 0.87 \\
\hline 8 peatmoss : 1 perlite : 1 vermiculite $(\mathrm{PL})$ & 1.19 & 4.37 & 6.30 & 0.26 & 0.51 & 3.20 & 3.92 & 0.69 & 0.90 & 0.36 & 0.53 & 0.65 & 0.71 \\
\hline 8 peatmoss : 1 perlite : $1 \mathrm{v}$ & 2.37 & 4.67 & 6.76 & 0.28 & 0.53 & 3.45 & 3.97 & 0.76 & 0.94 & 0.38 & 0.55 & 0.62 & 0.69 \\
\hline 8 peatmoss : 1 perlite : 1 vermiculite (PL) & 3.56 & 5.38 & 7.86 & 0.37 & 0.61 & 4.09 & 4.52 & 0.95 & 1.06 & 0.43 & 0.55 & 0.59 & 0.55 \\
\hline $4 \mathrm{WT}: 1$ peatmoss (WTP2) & & NS & $\mathrm{L}^{* *}$ & NS & $\mathrm{L}^{* *}$ & NS & NS & $\mathrm{L}^{*}$ & $\mathrm{~L}^{* * *}$ & NS & $\mathrm{L}^{*}$ & $\mathrm{~L}^{* *}$ & NS \\
\hline $1 \mathrm{WT}: 1$ peatmoss (WTP5) & & NS & $\mathrm{L}^{*}$ & NS & $\mathrm{L}^{* *}$ & NS & NS & $\mathrm{L}^{*}$ & $\mathrm{~L}^{* *}$ & NS & $\mathrm{L}^{*}$ & $\mathrm{Q}^{*}$ & NS \\
\hline 8 peatmoss : 1 perlite : 1 vermiculite (PL) & & $\mathrm{L}^{* *}$ & $\mathrm{~L}^{* * *}$ & $\mathrm{~L}^{* *}$ & $\mathrm{~L}^{* * *}$ & NS & NS & $\mathrm{L}^{* *}$ & $\mathrm{~L}^{* *}$ & $\mathrm{~L}^{*}$ & NS & NS & $\mathrm{L}^{* * *}$ \\
\hline
\end{tabular}

${ }^{\mathrm{z}}$ Supplemental starter fertilizer $(7 \mathrm{~N}-1.3 \mathrm{P}-8.2 \mathrm{~K})$.

${ }^{\text {y}}$ Results from USDA-ARS Southern Horticultural Laboratory, Poplarville, MS (Miss.) and Young's Plant Farm, Auburn, AL (Ala.).

${ }^{x}$ Processed whole pine tree (Pinus taeda) shoots ground to pass a $0.64-\mathrm{cm}$ screen.

"Tukey's honest significant difference $(P \leq 0.05, \mathrm{n}=4)$.

${ }^{v}$ Sufficiency ranges as published by Mills and Jones (1996).

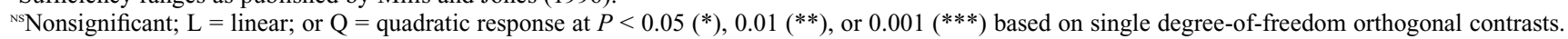

Table 7. Effects of starter fertilizer rate and substrate on tissue micronutrient content of Petunia $\times$ hybrida Dreams Purple at two different growing locations.

\begin{tabular}{|c|c|c|c|c|c|c|c|c|c|c|c|}
\hline \multirow[b]{2}{*}{ Substrate } & \multirow{2}{*}{$\begin{array}{c}\text { Fertilizer } \\
\left(\mathrm{kg} \cdot \mathrm{m}^{-3}\right)\end{array}$} & \multicolumn{2}{|c|}{$\mathrm{B}(\mathrm{ppm})$} & \multicolumn{2}{|c|}{$\mathrm{Fe}(\mathrm{ppm})$} & \multicolumn{2}{|c|}{$\mathrm{Mn}(\mathrm{ppm})$} & \multicolumn{2}{|c|}{$\mathrm{Cu}(\mathrm{ppm})$} & \multicolumn{2}{|c|}{$\mathrm{Zn}(\mathrm{ppm})$} \\
\hline & & Miss. $^{y}$ & $\overline{\text { Ala. }}$ & Miss. & $\overline{\text { Ala. }}$ & Miss. & Ala. & Miss. & $\overline{\text { Ala. }}$ & Miss. & $\overline{\text { Ala. }}$ \\
\hline $100 \%$ WholeTree (WT) & 1.19 & 22.3 & 26.7 & 90.6 & 114 & 426 & 247 & 22.9 & 19.7 & 93.7 & 92.1 \\
\hline $4 \mathrm{WT}: 1$ peatmoss (WTP2) & 0.00 & 18.6 & 25.9 & 89.0 & 102 & 246 & 222 & 16.4 & 17.3 & 116.4 & 78.9 \\
\hline 4 WT $: 1$ peatmoss (WTP2) & 1.19 & 20.2 & 27.9 & 86.3 & 108 & 305 & 295 & 16.1 & 20.2 & 61.7 & 91.4 \\
\hline $4 \mathrm{WT}: 1$ peatmoss (WTP2) & 2.37 & 17.8 & 28.5 & 104.4 & 106 & 441 & 482 & 17.8 & 21.1 & 68.7 & 156.2 \\
\hline $1 \mathrm{WT}: 1$ peatmoss (WTP5) & 1.19 & 19.0 & 26.5 & 91.6 & 109 & 327 & 338 & 14.9 & 18.2 & 73.8 & 69.6 \\
\hline $1 \mathrm{WT}: 1$ peatmoss (WTP5) & 2.37 & 16.6 & 28.2 & 90.1 & 112 & 384 & 381 & 15.6 & 19.8 & 48.5 & 72.1 \\
\hline 1 WT $: 1$ peatmoss (WTP5) & 3.56 & 19.4 & 27.6 & 99.0 & 111 & 423 & 434 & 17.3 & 21.7 & 92.5 & 81.7 \\
\hline 8 peatmoss : 1 perlite $: 1$ vermiculite $(\mathrm{PL})$ & 0.00 & 17.7 & 30.1 & 102.9 & 143 & 206 & 266 & 10.7 & 19.3 & 45.6 & 69.5 \\
\hline 8 peatmoss : 1 perlite : 1 vermiculite (PL) & 1.19 & 19.2 & 38.7 & 133.2 & 135 & 231 & 280 & 11.4 & 19.1 & 78.9 & 71.0 \\
\hline 8 peatmoss : 1 perlite : 1 vermiculite (PL) & 2.37 & 17.7 & 32.9 & 166.4 & 123 & 272 & 325 & 11.6 & 20.7 & 60.4 & 73.6 \\
\hline 8 peatmoss : 1 perlite $: 1$ vermiculite (PL) & 3.56 & 22.1 & 29.0 & 183.1 & 131 & 321 & 362 & 14.5 & 21.6 & 95.0 & 71.9 \\
\hline $4 \mathrm{WT}: 1$ peatmoss (WTP2) & & NS & NS & NS & NS & $\mathrm{L}^{* * *}$ & $\mathrm{~L}^{* * *}$ & NS & NS & $\mathrm{L}^{*}$ & $\mathrm{Q}^{*}$ \\
\hline 1 WT $: 1$ peatmoss (WTP5) & & NS & NS & NS & NS & $\mathrm{L}^{* *}$ & $\mathrm{~L}^{* * *}$ & NS & NS & NS & NS \\
\hline 8 peatmoss : 1 perlite : 1 vermiculite (PL) & & $\mathrm{L}^{*}$ & $\mathrm{Q}^{*}$ & $\mathrm{~L}^{* * *}$ & NS & $\mathrm{L}^{* *}$ & $\mathrm{~L}^{*}$ & NS & NS & NS & NS \\
\hline
\end{tabular}

${ }^{\mathrm{z}}$ Supplemental starter fertilizer $(7 \mathrm{~N}-1.3 \mathrm{P}-8.2 \mathrm{~K})$.

${ }^{\mathrm{y}}$ Results from USDA-ARS Southern Horticultural Laboratory, Poplarville, MS (Miss.) and Young's Plant Farm, Auburn, AL (Ala.).

${ }^{x}$ Processed whole pine tree (Pinus taeda) shoots ground to pass a $0.64-\mathrm{cm}$ screen.

"Tukey's honest significant difference $(P \leq 0.05, \mathrm{n}=4)$.

${ }^{v}$ Sufficiency ranges as published by Mills and Jones (1996).

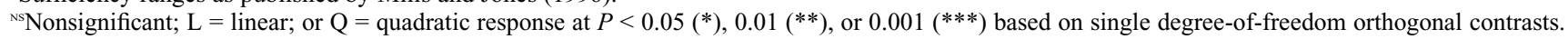

WT in Alabama (Table 5). Increasing SF resulted in decreased marigold flower count within the peat-lite in Mississippi; otherwise, marigold flower count was not affected by SF. In general, petunia in Alabama had more flowers than those in Mississippi, whereas marigold had less (Table 4). Additionally shoot dry weight (SDW) and growth index of petunia appeared to be greater for plants in Mississippi (Table 4). These differences between the two locations are attributed to differences in growing environment and cultural practices. Shoot dry weight of petunia increased with increasing fertilizer rate at both test locations and for all substrates except PL in Alabama. In general, dry weight of petunia was greatest for any substrate containing peatmoss with a SF rate of 2.37 $\mathrm{kg} \cdot \mathrm{m}^{-3}$ or greater. The exception is that in Alabama, petunia grown in WT at 3.56 $\mathrm{kg} \cdot \mathrm{m}^{-3} \mathrm{SF}$ had as high a SDW as any other 
treatment. Marigold dry weight was similar for all substrates in Mississippi where at least $1.19 \mathrm{~kg} \cdot \mathrm{m}^{-3} \mathrm{SF}$ was used. Marigold dry weight in Alabama was similar for WT at the $2.37 \mathrm{~kg} \cdot \mathrm{m}^{-3} \mathrm{SF}$ rate and all others containing peat except the WTP2 at the $0 \mathrm{~kg} \cdot \mathrm{m}^{-3}$ SF rate (Table 5).

There were no differences in root rating for petunia (data not shown). However, there was an increase in root rating with increase in SF rate for the WT and WTP2 substrates in Alabama, whereas there was a decrease in root rating with an increase in SF rate for WTP5 in Mississippi. In general, marigold root ratings seemed to be lower for plants in substrates with higher ECs indicating a possible high salt effect on rooting. There was a slight linear increase in substrate shrinkage for WT with increasing SF. There was also less shrinkage in $100 \% \mathrm{WT}$ at $0.00 \mathrm{~kg} \cdot \mathrm{m}^{-3}$ than WTP5 and PL across all SF rates.

Tissue $\mathrm{N}$ content for petunia increased with increasing SF rate for all substrates in Alabama and for WT and PL in Mississippi (Table 6). With the exception of WT (Mississippi) and WTP2 (Alabama) at the $0 \mathrm{~kg} \cdot \mathrm{m}^{-3}$ $\mathrm{SF}$ rate, all tissue $\mathrm{N}$ contents were within the reported sufficiency range (1.2\% to $2.8 \%$; Mills and Jones, 1996). Tissue Ca content increased with increasing SF rate for all substrates at both locations. However, with few exceptions, tissue $\mathrm{Ca}$ content was below the recommended range. Tissue manganese also increased with increasing SF rate with all substrates and both locations (Table 7). With the exception of WT at the $0 \mathrm{~kg} \cdot \mathrm{m}^{-3} \mathrm{SF}$ rate in Alabama, all tissue manganese concentrations were above the recommended range many by a factor of 2 to 3 . However, no visual signs of manganese toxicity were observed. Tissue iron for petunias was similar for all treatments in Alabama; however, in Mississippi, plants grown in PL with the addition of SF had higher tissue iron content than any other treatment.

Results achieved in this study are similar to other studies evaluating high wood fiber substrates (Boyer et al., 2006a, 2006b; Fain et al., 2006; Gruda and Schnitzler, 2001; Gruda et al., 2000a, 2000b; Wright and Browder, 2005). Potential concerns with WholeTree are lower CC combined with low $\mathrm{CEC}$ and possible $\mathrm{N}$ immobilization. These factors were the most likely contributors to the lower EC in substrates containing WholeTree. Close attention to watering practices are necessary to minimize leaching of nutrients in a substrate with higher AS and lower CC. However, it is possible to increase the CC of WholeTree by processing to a finer screen size and or blending different sizes together to achieve desired CC, AS, and TP.
Addition of wetting agents may also minimize leaching by increasing wettability, although no noticeable problems with rewetting occurred in this study. Because WholeTree is manufactured, it can also be produced with a consistent quality over time. WholeTree also opens a new market potential for the forestry industry. Unlike many other forest products as well as current wood fiber substrates, WholeTree uses the aboveground portions of the tree leaving virtually no residue on the forest floor. In a typical thinning or logging operation, residue can amount to $20 \%$ to $50 \%$ of the total biomass. Forest residues can also create additional costs to the forest operation because they must be removed or spread across the forest floor.

Results also reveal that with the addition of an adequate starter nutrient charge, WholeTree is an acceptable substrate component replacing the majority of peatmoss in production of petunia and marigold. Additionally, the wide range of particle sizes achieved from the production of WholeTree substrate provides needed structure and can eliminate the need for expensive aggregates such as perlite. What is most promising about WholeTree is the possibility of an economically sustainable greenhouse substrate, which could be available in close proximity to major horticultural production areas throughout the southeastern United States.

\section{Literature Cited}

Argo, W.R. and P.R. Fisher. 2002. Understanding $\mathrm{pH}$ management for container-grown crops. Meister Publishing, Willoughby, $\mathrm{OH}$.

Bachman, G.R. and J. Metzger. 1998. The use of vermicompost as a media amendment. Proc. South. Nur. Assn. Res. Conf. 43:32-33.

Barkham, J.P. 1993. For peat's sake: Conservation or exploitation? Biodiv. Conserv. 2:556-566.

Bilderback, T.E., W.C. Fonteno, and D.R. Johnson. 1982. Physical properties of media composed of peanut hulls, pinebark and peatmoss and their effects on azalea growth. J. Amer. Soc. Hort. Sci. 107:522-525.

Bohne, H. and C. Günther. 1997. Physical properties of peat determined with different methods. Acta Hort. 450:271-276.

Boyer, C.R., G.B. Fain, C.H. Gilliam, H.A. Torbert, T.V. Gallagher, and J.L. Sibley. 2006a. Evaluation of freshly chipped pine tree substrate for container grown Lantana camara. HortScience 41:1027 (abstr.).

Boyer, C.R., G.B. Fain, C.H. Gilliam, H.A. Torbert, T.V. Gallagher, and J.L. Sibley. 2006b. Alternative substrates for bedding plants. Proc. South. Nur. Assn. Res. Conf. 51:22-25.

Bragg, N.C. 1991. Peat and its alternatives. Horticultural Development Council, Petersfield, UK.

Conover, C.A. and R.T. Poole. 1983. Sedge moss peat, solite, and Melaluca quinquenervia as potting medium components for shadehouse production of foliage plants. HortScience 18:888-890.

Evans, M.R. 2004. Processed poultry feather fiber as an alternative to peat in greenhouse crops substrate. HortTechnology 14:176-179.

Evans, M.R. and R.H. Stamps. 1996. Growth of bedding plants in sphagnum peat and coir dustbased substrates. J. Environ. Hort. 14:187-190.

Fain, G.B., C.H. Gilliam, and J.L. Sibley. 2006. Evaluation of an alternative, sustainable substrate for use in greenhouse crops. Proc. South. Nur. Assn. Res. Conf. 51:651-654

Fain, G.B., C.H. Gilliam, J.L. Sibley, and C.R. Boyer. 2008. Establishment of greenhouse grown Tagetes patula and Petunia $\times$ hybrida in 'WholeTree' substrates. Acta Hort. (in press).

Fischer, P. 1994. Holzreststoffe als Bestandteil von Kulturubstraten. Deutshcher Gartenbau 28:1726-1729.

Grantzau, E. 1991. Noch Vorsicht mit holzfasersubstraten. Deutshcher Gartenbau 51:2150 2154.

Gruda, N. and W.H. Schnitzler. 2001. Physical properties of wood fiber substrates and their effect on growth of lettuce seedlings (Lactuca sativa L. var. capitata L.). Acta Hort. 548:415423.

Gruda, N., Ch. Sippel, and W.H. Schnitzler. 2000a. Investigation of physical properties of woodfiber substrates under press pot conditions. Acta Hort. 554:51-57.

Gruda, N., S.V. Tucher, and W.H. Schnitzler. 2000b. N- immobilization of wood fiber substrates in the production of tomato transplants [Lycopersicon lycopersicum (L.) Karts. ex. Farw.]. J. Appl. Bot. 74:32-37.

Gumy, N. 2001. Toresa ${ }^{\circledR}$ and other wood-fibre products; advantages and drawbacks when used in growing media. In: Proceedings of the International Peat Symposium-Peat in horticulture-Peat and its alternatives in growing media.

Kenna, S.W. and C.E. Whitcomb. 1985. Hardwood chips as an alternative medium for container plant production. HortScience 20:867-869.

Mills, H.A. and J.B. Jones. 1996. Plant analysis handbook II. MicroMacro Publishing, Athens, GA

Muro, J., I. Irigoyen, P. Samitier, P. Mazuela, M.C. Salas, J. Soler, and M. Urrestarazu. 2005. Word fiber as growing medium in hydroponic crop. Acta Hort. 697:179-185.

Owings, A.D. 1993. Cotton gin trash as a medium component in production of 'Golden Bedder' coleus. Proc. Southern Nursery Assn. Res. Conf. 38:65-66.

Robertson, A. 1993. Peat, horticulture and environment. Biodiv. Conserv. 2:541-547.

Saunders, T.N., J.F. Browder, B.E. Jackson, and R.D. Wright. 2006. Particle size of a pine chips substrate affects plant growth. Proc. South. Nur. Assn. Res. Conf. 51:46-48.

Wright, R.D. 1986. The pour-through nutrient extraction procedure. HortScience 21:227229.

Wright, R.D. and J.F. Browder. 2005. Chipped pine logs: A potential substrate for greenhouse and nursery crops. HortScience 40:1513-1515. 